Journal of Management and Bussines (JOMB)

Volume 1, Nomor 2, Desember 2019

p-ISSN : 2656-8918

e-ISSN:2684-8317

DOI : https://doi.org/10.31539/jomb.v1i2.888

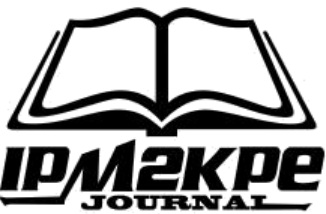

\title{
ANALISIS LAPORAN KEUANGAN UNTUK MENGUKUR KINERJA KEUANGAN PERUSAHAAN TELEKOMUNIKASI YANG TERDAFTAR DI BURSA EFEK INDONESIA
}

\author{
Mujari \\ Sekolah Tinggi Ilmu Ekonomi Serelo Lahat \\ Mujari262729@gmail.com
}

\begin{abstract}
ABSTRAK
Penelitian ini bertujuan untuk menilai kinerja keuangan PT Telekomunikasi Indonesia Tbk dengan cara menganalisis laporan keuangan menggunakan rasio keuangan. Data penelitian ini diperoleh dari Bursa Efek Indonesia (BEI). Hasil penelitian menunjukkan kinerja PT Telekomunikasi Indonesia Tbk berdasarkan rasio likuiditas pada tahun 2015 sampai tahun 2018 kurang baik, dimana Current Ratio (CR) perusahaan pada tahun 2015 sampai dengan tahun 2018 kurang dari 100\%. Simpulan, Rasio solvabilitas PT Telekomunikasi Indonesia Tbk pada tahun 2015 sampai tahun 2018 baik, dimana Debt to Assets Ratio (DAR) perusahaan pada tahun 2015 sampai tahun 2018 tidak lebih dari 100\%. Rasio profitabilitas PT Telekomunikasi Indonesia Tbk pada tahun 2015 sampai tahun 2018 adalah baik, dimana hasil perhitungan rasio profitabilitas lebih besar dari sukubunga deposito berjangka satu tahun. Rasio aktivitas PT Telekomunikasi Indonesia Tbk pada tahun 2015 sampai tahun 2018 kurang baik, dimana Total Asset Turn Over (TATO) kurang dari 1, yang artinya perusahaan kurang produktif.
\end{abstract}

Kata Kunci: Laporan Keuangan, Kinerja Keuangan, Rasio Keuangan

\section{ABSTRACT}

This study aims to assess the financial performance of PT Telekomunikasi Indonesia Tbk by analyzing financial statements using financial ratios. The research data was obtained from the Indonesia Stock Exchange (IDX). The results showed the performance of PT Telekomunikasi Indonesia Tbk based on liquidity ratios from 2015 to 2018 was not good, where the company's Current Ratio (CR) in 2015 to 2018 was less than 100\%. The solvency ratio of PT Telekomunikasi Indonesia Tbk in 2015 to 2018 is good, where the company's Debt to Assets Ratio (DAR) in 2015 to 2018 is no more than 100\%. The profitability ratio of PT Telekomunikasi Indonesia Tbk in 2015 to 2018 is good, where the results of the calculation of profitability ratios are greater than the one-year time deposit interest rate. The ratio of activities of PT Telekomunikasi Indonesia Tbk in 2015 to 2018 is not good, where the Total Assets Turn Over (TATO) is less than 1, which means the company is less productive.

Keywords: Financial Statement, Financial Performance, Financial Ratios 


\section{PENDAHULUAN}

Laporan keuangan merupakan proses akhir dalam proses akuntansi yangmempunyai peranan penting bagi pengukuran dan penilaian kinerja sebuah perusahaan. Perusahaan-perusahaan di Indonesia, khususnya perusahaan yang go public diharuskan membuat laporan keuangan setiap periodenya. Laporan keuangan tersebut mempunyai tujuan untuk memberikan informasi tentang posisi keuangan, kinerja, dan arus kas perusahaan yang bermanfaat bagi sebagian besar kalangan pengguna laporan dalam rangka membuat keputusan-keputusan ekonomi serta menunjukkan pertanggungjawaban (stewardship) manajemen atas penggunaan sumber-sumber daya yangdipercayakan kepada mereka.

Dewasa ini, banyak perusahaan berskala besar atau kecil baik yang bersifat profit maupun non profit, mempunyai perhatian yang besar di bidang keuangan. Dalam perkembangan dunia usaha yang semakin maju, persaingan antara satu perusahaan dengan perusahaan lainnya semakin tinggi mengakibatkan adanya perusahaan yang tiba-tiba mengalami kemunduran. Oleh karena itu, agar perusahaan dapat bertahan dan bisa tumbuh berkembang, perusahaan harus mencermati kondisi dan kinerja perusahaan. Untuk mengetahui dengan tepat bagaimana kondisi dan kinerja perusahaan maka dibutuhkan pula suatu analisis yang tepat.

Pada mulanya laporan keuangan bagi suatu perusahaan hanyalah sebagai alat penguji dari pekerjaan bagian pembukuan. Selanjutnya, laporan keuangan tidak hanya sebagai alat penguji saja, tetapi juga sebagai dasar untuk dapat menentukan atau menilai posisi keuangan perusahaan yang bersangkutan dengan melakukan analisis. Melalui hasil analisis tersebut, dapat diketahui pengunaan sumber-sumber ekonomi, kewajiban yang harus dipenuhi dan modal yang dimiliki oleh perusahaan, serta hasil-hasil yang telah dicapai perusahaan tersebut.

Media yang dapat dipakai untuk menilai kinerja perusahaan adalah laporan keuangan. Laporan keuangan adalah gambaran tentang hasil atau perkembangan usaha perusahaan. Laporan keuangan tersebut digunakan untuk membantu para pemakai laporan keuangan dalam menilai dan mengukur kinerja perusahaan sehingga dapat mengambil keputusan yang tepat. 
Kinerja keuangan suatu perusahaan dapat diukur dan dilihat melalui laporan keuangan dengan cara menganalisis laporan keuangan. Harahap (2013) mengatakan bahwa kegiatan analisis laporan keuangan merupakan salah satu media untuk mendapatkan informasi yang lebih banyak, lebih baik, akurat, dan dijadikan sebagai bahan dalam proses pengambilan keputusan. Analisis laporan keuangan merupakan alat yang sangat penting untuk memperoleh informasi yang berkaitan dengan posisi keuangan perusahaan serta hasil-hasilyang telah dicapai sehubungan dengan pemilihan stategi perusahaan yang akan ditetapkan. Selain itu, dengan melakukan analisis laporan keuangan perusahaan, maka pimpinan perusahaan dapat mengetahui keadaan finansial perusahaan serta hasil-hasil yang telah dicapai diwaktu lampau dan diwaktu yang sedang berjalan.

Sebagaimana diketahui, tujuan utama laporan keuangan adalah menyediakan informasi yang menyangkut posisi keuangan, kinerja serta perubahan posisi keuangan suatau perusahaan yang bermanfaat bagi sejumlah besar pemakainya dalam pengambilan keputusan ekonomi. Artinya, Laporan keuangan merupakan alat untuk memperoleh informasimengenai posisi keuangan dan hasil operasi yang telah dicapai oleh suatu perusahaan. Informasi tersebut nantinya akan digunakan sebagai bahan pertimbangan dalam pengambilan keputusan, baik oleh manajemen perusahaan maupun pihak ekstern perusahaan.

Sehubungan dengan penilaian kinerja keuangan perusahaan, PT Telekomunikasi Indonesia Tbk menarik bagi penulis untuk diteliti. Perusahaan tersebut adalah salah satu perusahaan telekomunikasi terbesar di Indonesia di mana pada tahun2014 meraup laba 12.850 Miliar, tahun 2015 meraup laba 14.205 Miliar, tahun 2016 meraup laba 14.471 Miliar, tahun 2017 meraup laba 15.489 Miliar dan tahun 2018 meraup laba bersih Rp 19.352 Miliar, meningkat 24,9 \% dari periode sebelumnya (www.idx.co.id).

\section{KAJIAN TEORI}

\section{Pengertian Laporan Keuangan}

Laporan keuangan keuangan merupakan suatu informasi yang menggambarkan kondisi suatu perusahaan, dimana selanjutnya itu akan menjadi suatu informasi yang menggambarkan tentang kinerja suatu perusahaan. 
Menurut Farid dan Siswanto dalam (Fahmi, 2012) mangatakan bahwa laporan keuangan merupakan informasi yang diharapkan mampu memberikan bantuan kepada pengguna untuk membuat keputusan ekonomi yang bersifat finansial. Menurut Weston dalam Kasmir (2012) bentuk-bentuk rasio keuangan adalah:

\section{Rasio Likuiditas}

Menunjukkan kemampuan perusahaan untuk memenuhi kewajibannya dalam jangka pendek. Perusahaan dalam keadaan likuid apabila perusahaan mampu memenuhi kewajiban keuangannya tepat pada waktunya. Perusahaan dikatakan dapat memenuhi kewajiban keuangannya tepat waktu apabila perusahaan tersebut mempunyai alat pembayaran atau aktiva lancar yang lebih besar daripada hutang lancarnya. Semakin tinggi rasio likuiditas maka semakin baik kondisi keuangan perusahaan karena menunjukkan bahwa perusahaan dalam keadaan yang likuid.

2. Rasio Solvabilitas

Menunjukkan kemampuan perusahaan dalam memenuhi kewajiban jangka panjang. Suatu perusahaan dikatakan solvabel apabila perusahaan tersebut mempunyai aktiva yang cukup untuk membayar semua hutang-hutangnya. Rasio ini dapat dihitung berdasarkan informasi dari neraca, yaitu pos-pos aktiva dan pos-pos hutang.

\section{Rasio Aktivitas}

Rasio ini menunjukkan kemampuan perusahaan dalam memanfaatkan harta yang dimilikinya. Rasio ini difokuskan pada keefektifan perusahaan dalam mengelola dua kelompok aktiva khusus, piutang dan persediaan dan total aktiva secara keseluruhan. Semakin besar rasio yang didapat maka semain baik karena perusahaan semakin cepat mengubah persediaannya menjadi kas.

4. Rasio Rentabilitas,

Menunjukkan kemampuan dari perusahaan dalam menghasilkan keuntungan. Rentabilitas suatu perusahaan diukur dengan kesuksesan perusahaan dan kemampuan menggunakan aktivanya secara produktif, dengan demikian rentabilitas suatu perusahaan dapat diketahui dengan memperbandingkan antara laba yang diperoleh dalam suatu periode dengan jumlah aktiva atau jumlah modal perusahaan tersebut. 


\section{METODE PENELITIAN}

Jumlah Populasi dalam penelitian ini adalah Laporan Keuangan PT. Telekomunikasi dari tahun 1956 sampai dengan tahun 2018. Teknik penarikan sampel yang digunakan dalam penelitian ini adalah teknik purposive sampling yaitu teknik untuk menentukan sampel penelitian dengan beberapa pertimbangan tertentu yang bertujuan agar data yang diperoleh nantinya bisa lebih representatif. Dari pertimbangan tersebut dapat ditarik sampel laporan keuangan dari tahun 2015-2018.

\section{HASIL PENELITIAN}

\section{Rasio Likuiditas PT Telekomunikasi Indonesia Tbk}

Rasio likuiditas adalah rasio yang bertujuan untuk mengetahui kemampuan perusahaan dalam membayar kewajiban jangka pendek, meliputi:
a. Current Ratio (CR)
$=$
$\underline{\text { Aktiva lancar }}$
Kewajiban lancar
b. Quick Test Ratio $(Q T R)=$

\begin{tabular}{c|} 
Aktiva lancar \\
Kewajiban lancar
\end{tabular}
c. Net Working Capital $(N W C)=$

Kas+Investasi jangka
pendek+piutang dagang bersih
Kewajiban lancar
$\underline{\text { Aktiva Lancar-Kewajiban }}$
$\underline{\text { Lancar }}$
Kewajiban Lancar

Hasil penelitian menunjukkan bahwa besarnya rasio lancar (Current Ratio) PT Telekomunikasi Indonesia Tbk pada tahun 2015 adalah 54\%, tahun 2016 adalah 61\%, tahun 2017 adalah $91 \%$ dan tahun 2018 adalah $96 \%$.

\section{Rasio Solvabilitas PT Telekomunikasi Indonesia Tbk}

Rasio solvabilitas adalah rasio untuk mengetahui kemampuan perusahaan dalam membayar kewajiban jika perusahaan tersebut dilikuidasi. Rasio ini meliputi:

a. Debt to Assets Ratio $(D A R)=\frac{\text { Total kewajiban }}{\text { Total aktiva }}$


b. Debt to Equity Ratio $(D E R)=\frac{\text { Total kewajiban }}{\text { Total ekuitas }}$
c. Interest Coverage $(I C)=$
\begin{tabular}{l}
$\frac{\text { EBIT }}{\text { Biaya Bunga }}$ \\
\hline
\end{tabular}

Hasil penelitian menunjukkan Debt to Assests Ratio (DAR) atau rasio utang terhadap aktiva PT Telekomunikasi Indonesia Tbk pada tahun 2015 adalah 52\%, pada tahun 2016 adalah 49\%, pada tahun 2017 adalah 44\% dan pada tahun 2018 adalah $41 \%$. Maksud dari rasio ini adalah bahwa pada tahun 2015 PT Telekomunikasi Indonesia Tbk menggunakan dana dari kreditur sebesar 52\%, tahun 2016 sebesar 49\%, tahun 2017 sebesar $44 \%$ dan tahun 2018 sebesar $41 \%$ dari total aktiva yang dimilikinya. Persentase DAR yang semakin menurun setiap tahunnya menunjukkan bahwa sebagian besar investasi didanai oleh modal sendiri, bukan utang. Rasio utang terhadap modal atau Debt to Equity Ratio (DER) pada tahun 2013 adalah 138\%, tahun 612014 adalah 122\%, tahun 2015 adalah $78 \%$ dan tahun 2016 adalah $69 \%$.

\section{Rasio Profitabilitas PT Telekomunikasi Indonesia Tbk}

Rasio profitabilitas adalah rasio yang bertujuan untuk mengetahui kemampuan perusahaan dalam menghasilkan laba. Rasio ini meliputi:

a. Return On Assets $($ ROA $)=$\begin{tabular}{l|}
$\frac{\text { Laba Bersih }}{\text { Total Aktiva }}$ \\
\hline
\end{tabular}

b. Return On Equity $(R O E)=\frac{\text { Laba Bersih }}{\text { Rata - Rata Ekuitas }}$

Hail penelitian menunjukkan bahwa Return on Asset (ROA) pada tahun 2015 sebesar 11,64\%, tahun 2016 sebesar 11,62\%, tahun 2017 sebesar 11,48 dan tahun 2018 sebesar 15,02\%. Ini berarti setiap Rp 1 aktiva mampu menghasilkan laba bersih Rp 0,1164 pada tahun 2015, Rp 0,1162 pada tahun 2016, Rp 0,1148 pada tahun 2017 dan Rp 0,1502 pada tahun 2018. Sedangkan Return on Equity (ROE) pada tahun 2015 sebesar 31,20\%, tahun 2016 sebesar 30,92\%, tahun 2017 sebesar 24,19\% dan tahun 
2018 sebesar 26,37\%. Persentase ini menggambarkan bahwa setiap Rp 1 modal mampu menghasilkan Rp 0,3120 pada tahun 2013, Rp 0,3092 pada tahun 2014, Rp 0,2419 pada tahun 2015 dan Rp 0,2637 pada tahun 2016.

\section{PEMBAHASAN}

Berdasarkan hasil penelitian yang menunjukkan bahwa besarnya rasio lancar (Current Ratio) PT Telekomunikasi Indonesia Tbk pada tahun 2015 adalah 54\%, tahun 2016 adalah 61\%, tahun 2017 adalah 91\% dan tahun 2018 adalah 96\%. Rasio ini menggambarkan bahwa setiap Rp 1 utang lancar dijamin dengan aktiva lancar sebesar Rp 0,54 untuk tahun 2015, Rp 0,61 untuk tahun 2016, Rp 0,91 untuk tahun 2017 dan Rp 0,96 untuk tahun 2018. Hal tersebut menunjukkan bahwa PT Telekomunikasi Indonesia Tbk kurang mampu membayar kewajiban jangka pendeknya dengan aktiva lancar yang dimiliki.Walaupun demikian, persentase rasio lancar PT Telekomunikasi Indonesia Tbk mengalami peningkatan setiap tahunnya selama empat tahun tersebut.

Sedangkan Quick Test Ratio (QTR) atau rasio cepat PT Telekomunikasi Indonesia Tbk pada tahun 2015 adalah 40\%, tahun 2016 adalah 45\%, tahun 2017 adalah $68 \%$ dan tahun 2018 adalah $67 \%$. Itu artinya rasio cepat menunjukkan peningkatan dari tahun 2015 sampai dengan tahun 2017 dan pada tahun 2018 mengalami penurunan 1\% dari tahun sebelumnya. Sementara rasio modal kerja bersih atau Net Working Capital (NWC) PT Telekomunikasi Indonesia Tbk mengalami peningkatan dari tahun ke tahun.Hal ini dapat dilihat pada aktiva lancar yang terus meningkat dan kewajiban lancar yangcenderung mengalami penurunan setiap tahunnya. Rule of thumb (pedoman) dalam menganalisis adalah current ratio antara $100 \%$ s.d. $200 \%$. Diatas $200 \%$ berarti banyak aktiva menganggur (Darsono, Ashari, 2012).

Hasil penelitian ini juga menunjukkan Debt to Assests Ratio (DAR) atau rasio utang terhadap aktiva PT Telekomunikasi Indonesia Tbk pada tahun 2015 adalah 52\%, pada tahun 2016 adalah 49\%, pada tahun 2017 adalah 44\% dan pada tahun 2018 adalah 41\%. Maksud dari rasio ini adalah bahwa pada tahun 2015 PT Telekomunikasi Indonesia Tbk menggunakan dana dari kreditur sebesar 52\%, tahun 2016 sebesar 49\%, tahun 2017 sebesar 44\% dan tahun 2018 sebesar 41\% dari total aktiva yang dimilikinya. Persentase DAR yang semakin menurun setiap tahunnya menunjukkan bahwa sebagian besar investasi didanai oleh modal sendiri, bukan utang. 
Penelitian ini juga menunjukkan rasio utang terhadap modal atau Debt to Equity Ratio (DER) pada tahun 2013 adalah 138\%, tahun 612014 adalah 122\%, tahun 2015 adalah 78\% dan tahun 2016 adalah 69\%. Artinya setiap Rp 1 modal perusahaan menjamin utang perusahaan senilai Rp 1,38 untuk tahun 2013, Rp 1,22 untuk tahun 2014, Rp 0,78 untuk tahun 2015 dan Rp 0,69 untuk tahun 2016. Semakin kecil rasio ini berarti semakin besar jumlah aktiva yang didanai oleh modal perusahaan Sama halnyadengan Deb to Assets Ratio (DAR) dan Debt to Equity Ratio (DER), rasio Equity Multiplier (EM) juga mengalami penurunan selama empat tahun terakhir. Sementara itu, rasio Interest Coverage (IC) perusahaan pada tahun 2015 adalah 14,10 kali, pada tahun 2016 adalah 11.30 kali, pada tahun 2017 adalah 11,89 kali dan pada tahun 2018 adalah 13,41 kali. Semakin besar rasio ini menunjukkan bahwa laba yang tersedia untuk membayar biaya bunga juga semakin semakin besar.

Dapat disimpulkan bahwa rasio solvabilitas PT Telekomunikasi Indonesia Tbk selama empat tahun adalah baik, dimana perusahaan mampu membayar semua kewajibannya apabila perusahaan dilikuidasi. Rule of thumb dari rasio solvabilitas adalah maksimal 100\%. Artinya perusahaan banyak mengandalkan modal dari dalam, bukan utang (Darsono, Ashari, 2012).

Return on Asset (ROA) pada tahun 2015 sebesar 11,64\%, tahun 2016 sebesar 11,62\%, tahun 2017 sebesar 11,48 dan tahun 2018 sebesar 15,02\%. Ini berarti setiap Rp 1 aktiva mampu menghasilkan laba bersih Rp 0,1164 pada tahun 2015, Rp 0,1162 pada tahun 2016, Rp 0,1148 pada tahun 2017 dan Rp 0,1502 pada tahun 2018. Sedangkan Return on Equity (ROE) pada tahun 2015 sebesar 31,20\%, tahun 2016 sebesar 30,92\%, tahun 2017 sebesar 24,19\% dan tahun 2018 sebesar 26,37\%. Persentase ini menggambarkan bahwa setiap Rp 1 modal mampu menghasilkan Rp 0,3120 pada tahun 2013, Rp 0,3092 pada tahun 2014, Rp 0,2419 pada tahun 2015 dan Rp 0,2637 pada tahun 2016. Rule of thumb pada setiap rasio ini adalah bahwa hasil perhitungan rasio harus lebih besar dari bunga deposito berjangka satu tahun. Jika hasil perhitungan rasio lebih kecil dari suku bunga satu tahun, maka hasil investasi yang dilakukan lebih kecil daripada investasi pada deposito berjangka (Darsono, Ashari, 2012). 


\section{SIMPULAN}

Berdasarkan hasil penelitian dan pembahasan yang dilakukan oleh peneliti pada PT Telekomunikasi Indonesia Tbk, maka peneliti dapat menyimpulkan:

1. Kinerja PT Telekomunikasi Indonesia Tbk berdasarkan rasio likuiditas pada tahun 2015 sampai tahun 2018 kurang baik, dimana Current Ratio(CR) perusahaan pada tahun 2015 adalah 54\%, tahun 2016 adalah 61\%, tahun 2015 91\% dan tahun 2018 adalah 96\%. Itu artinya PT Telekomunikasi Indonesia Tbk tidak mampu membayar semua kewajiban lancarnya dengan aset lancar yang tersedia.

2. Rasio solvabilitas PT Telekomunikasi Indonesia Tbk pada tahun 2015 sampaitahun 2018 baik, dimana Debt to Assets Ratio (DAR) perusahaan pada tahun 2015 sebesar 52\%, tahun 2016 sebesar 49\%, tahun 2017 sebesar 44\% dan tahun 2018 sebesar 41\%. Persentase ini menunjukkan bahwa perusahaan lebih banyak mengandalkan modal dari dalam, bukan utang.

3. Sedangkan rasio profitabilitas PT Telekomunikasi Indonesia Tbk pada tahun 2015 sampai tahun 2018 adalah baik, dimana hasil perhitungan rasio profitabilitas lebih besar dari sukubunga deposito berjangka satu tahun. Sementara rasio aktivitas PT Telekomunikasi Indonesia Tbk pada tahun 2015 sampai tahun 2018 kurang baik dimana Total Asset Turn Over (TATO) kurang dari 1, yang artinya perusahaan kurang produktif. 


\section{DAFTAR PUSTAKA}

Darsono, D., Ashari, A. (2005). Pedoman Praktis Memahami Laporan Keuangan. Yogyakarta: Andi Offset

Fahmi, F., Irham, I. (2012). Analisis Laporan Keuangan. Lampulo: Alfabeta Kasmir, K. (2012). Manajemen Perbankan.Jakarta: PT RajaGrafindo Persada Syafri, H. F. (2013). Teori Akuntansi Edisi Revisi 2013. Jakarta: Rajawali Pers www.idx.co.id. Ringkasan Kinerja Perusahaan Tercatat. (online) 